\title{
Helseøkonomisk evaluering ved Nasjonalt kunnskapssenter for helsetjenesten
}

\author{
Gunhild Hagen, Torbjørn Wisløff og Marianne Klemp \\ Seksjon for legemidler og helseøkonomi, Nasjonalt kunnskapssenter for helsetjenesten \\ Korrespondanse: Marianne Klemp, E-post: marianne.klemp@kunnskapssenteret.noＴelefon: 93419895
}

\begin{abstract}
SAMMENDRAG
På grunn av begrensede ressurser kan ikke alle nye metoder som er effektive bli introdusert i helsevesenet. Det er derfor nødvendig å prioritere mellom disse nye metodene. Helseøkonomiske evalueringer kan være et nyttig verktøy for å synliggjøre kostnader og helseeffekter knyttet til ulike metoder.

Helseøkonomiske evalueringer er en integrert del av de fleste medisinske metodevurderinger (HTAs) utført av Nasjonalt kunnskapssenter for helsetjenesten (Kunnskapssenteret). Disse helseøkonomiske evalueringene er vanligvis basert på modeller som bruker forskjellige typer publiserte data for å beregne forventede kostnader og helseeffekter knyttet til ulike behandlingsalternativer.

I denne artikkelen presenterer vi noe av det metodiske grunnlaget for økonomiske evalueringer utført ved Kunnskapssenteret. Vi beskriver hvordan vi går fram for å sette opp en slik modell og diskuterer noen av de ulike typer av data som er nødvendige. En egen seksjon på følsomhetsanalyser og usikkerhetsaspekter er gitt på slutten, og dette kobles til et annet mulig resultat av helseøkonomiske evalueringer: kostnadseffektiviteten av å utføre ny forskning.
\end{abstract}

Hagen G, Wisløff T, Klemp M. Health economic evaluation at the Norwegian Knowledge Centre for the Health Services (NOKC). Nor J Epidemiol 2013; 23 (2): 157-164.

\section{ENGLISH SUMMARY}

Due to resource constraints, all new interventions that are effective cannot be introduced into the health care system. Hence, it is necessary to prioritize between these new interventions. Health economic evaluations can be a useful tool to illustrate the costs and health outcomes associated with different treatment options.

Health economic evaluations are an integral part of most health technology assessments (HTAs) performed by the Norwegian Knowledge Centre for the Health Services (NOKC). These health economic evaluations are usually based on models that synthesize different types of published data, in order to calculate the expected costs and health outcomes associated with different diagnostic or treatment options.

In this article we present parts of the methodological basis for economic evaluations conducted at NOKC. We describe how to set up a decision model and discuss some of the different types of data required. A special section on sensitivity and uncertainty aspects are given at the end, providing a link to a second output from health economic evaluations: cost-effectiveness of conducting new research.

This is an open access article distributed under the Creative Commons Attribution Licence, which permits unrestricted use, distribution, and reproduction in any medium, provided the original work is properly cited.

\section{INNLEDNING}

En medisinsk metodevurdering (engelsk: Health Technology Assessment, HTA) inneholder i tillegg til en systematisk oversikt om effekt av tiltak også analyser av konsekvenser ved å innføre en ny metode. Dette kan være analyser av økonomiske, organisatoriske, etiske og juridiske konsekvenser for pasient og samfunn. En vurdering av to eller flere av disse aspektene kalles i Norge for en fullstendig metodevurdering. I denne artikkelen bruker vi det utvidede medisinske metodebegrepet som definert av blant annet Håheim og Mørland (1). En medisinsk metode er i denne sammenhengen "alle tiltak for å forebygge, diagnostisere og behandle" og dekker dermed både legemidler, medisinskteknisk utstyr, prosedyrer og organisatoriske tiltak.

Metodevurderinger er ment å inngå som grunnlag i en beslutningsprosess og hvilke konsekvenser som be- lyses vil variere med problemstillingen (1). En fullstendig metodevurdering vil, som et minimum, alltid omfatte en vurdering av effekt, sikkerhet og kostnadseffektivitet av tiltaket. Hvorvidt en ny metode virker bedre og/eller gir mindre bivirkninger enn en eksisterende, er åpenbart viktige spørsmål for helsetjenesten. Ettersom ressursene er begrensede, er det også relevant å undersøke hvorvidt den eventuelle økte kostnaden ved en ny metode står i et rimelig forhold til helseeffekten, slik det er henvist til blant annet i Pasientrettighetsloven og Prioriteringsforskriften $(2,3)$. Dette rimelighetsforholdet blir noen ganger omtalt som grenser eller terskler for kostnadseffektivitet (4). Bakgrunnen for denne typen analyser er at beslutningstakere trenger hjelp til å vurdere for hvilke metoder kostnaden står i et rimelig forhold til helseeffekten. Dette er vanskelig, om ikke umulig å avgjøre uten at informasjon om effekt, sikkerhet og kostnader sees under ett. 


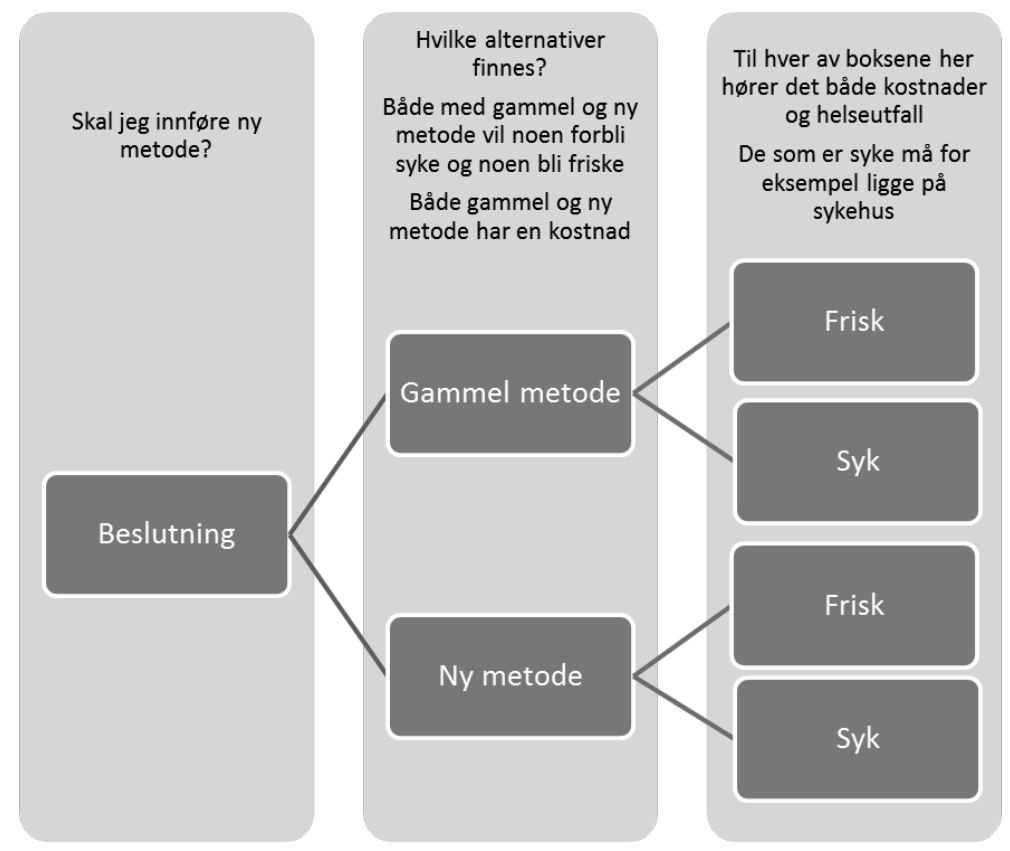

Figur 1. Enkelt beslutningstre.

\section{OVERFØRBARHET AV HELSEØKONOMISKE EVALUERINGER}

Noen ganger blir helseøkonomiske evalueringer utført som systematiske oversikter over publiserte økonomiske evalueringer fra andre land. Denne tilnærmingen brukes nå i relativt liten grad ved Kunnskapssenteret, fordi overføringsverdien av disse analysene til norske forhold kan være liten på grunn av ulik sykdomsforekomst, ulikheter i kostnadsnivå, ulikheter i medisinsk praksis, ulike organisatoriske forhold og ulike metodiske valg $(5,6)$. Publiserte analyser fra andre land kan bidra til å synliggjøre viktige avveininger ved en ny metode. De kan også være svært nyttige ved oppstart av et nytt modelleringsprosjekt (7). Man kan imidlertid ikke konkludere om kostnadseffektivitet under norske forhold på basis av en utenlandsk økonomisk evaluering (8). Selv om dette noen ganger blir gjort, er det viktig å være klar over at det å oversette en kostnadeffektbrøk (incremental-cost-effectiveness-ratio, ICER) fra for eksempel England til norske kroner ikke gir et korrekt bilde av kostnadseffektiviteten av bruken av en metode under norske forhold.

\section{HVORDAN UTFØRER VI HELSEØKONOMISKE EVALUERINGER}

Helseøkonomiske evalueringer kan utføres som en del av en sammenliknende effektstudie, som en ren modellberegning eller som en kombinasjon av disse to tilnærmingene. Ved Kunnskapssenteret blir helseøkonomiske evalueringer i hovedsak gjennomført som rene modellanalyser basert på egenutviklede modeller og en syntese av ulike publiserte eller andre offentlig tilgjengelige data. Unntaksvis vil vi benytte en eksisterende modell utviklet av andre eller lage en rapport basert på en systematisk gjennomgang av allerede publiserte helseøkonomiske evalueringer. Fordelen med å utvikle en egen modell er at det blir en uavhengig analyse skreddersydd for norske forhold. Vi har dermed god oversikt over forutsetninger og antakelser som ligger til grunn for analysen og har mulighet for å endre disse etter innspill fra kliniske eksperter eller eksterne fagfeller. Ulempen er at modellutvikling er en tid- og kompetansekrevende prosess og at beslutningstakere ikke alltid har tid til å vente på et slikt produkt. Hvor tidkrevende en slik prosess er, avhenger av kompleksiteten av sykdommen som den aktuelle behandlingen er rettet mot og hvilket detaljnivå vi legger oss på i analysen.

\section{Beslutningstraer og Markov-modeller}

Utgangspunktet for en modellanalyse er at vi gjerne vil vite hva som hadde skjedd dersom pasienter i den norske befolkningen fikk en gitt behandling, sammenliknet med hva som ville skjedd hvis de fikk en annen behandling. Ofte vil det være snakk om å sammenlikne en ny behandling med den behandling som tilbys $i$ dag. Formålet med en modellanalyse er å lage en slags beste gjetning på hva som ville skjedd dersom den nye behandlingen ble tatt i bruk. I praksis gjøres dette ved å lage en beslutningsmodell, som oftest i form av et beslutningstre eller en Markov-modell, men andre oppsett er også mulige og noen ganger nødvendig (9). Et beslutningstre er godt egnet hvis man evaluerer en relativt enkel metode der det ikke er nødvendig å studere konsekvenser over et lengre tidsperspektiv. Ett eksempel på et enkelt beslutningstre er vist i figur 1 .

Ut fra beslutningstreet regnes forventede kostnader og forventede helseeffekter ved ny metode sammenliknet med gammel metode. Eksempel: gammel metode koster 500 kroner og ny metode 1000 kroner. Ved be- 


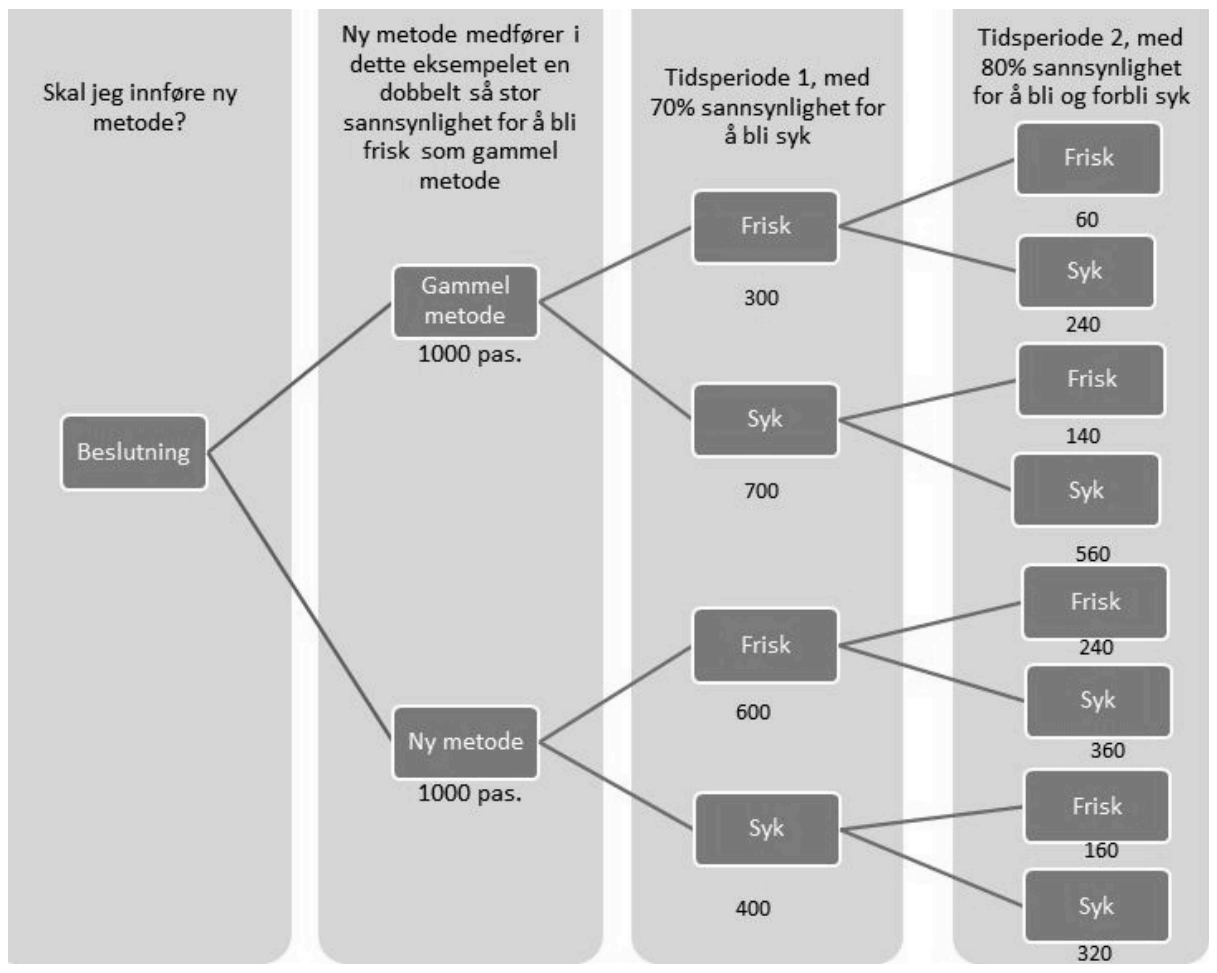

Figur 2. Beslutningstre med to tidsperioder.

handling med gammel metode vil 300/1 000 bli friske og med ny metode vil 600/1 000 bli friske. Å være syk koster 2000 kroner, mens det ikke er noen kostnader knyttet til det å være frisk. Forventet kostnad ved gammel metode blir da (i gjennomsnitt per pasient):

$500+([700 / 1000] \cdot 2000)+([300 / 1000] \cdot 0)=1900$

og ved ny metode

$1000+([400 / 1000] \cdot 2000)+([600 / 1000] \cdot 0)=1800$.

Hvis vi så teller frisk som 1 og syk som 0 , blir forventet helseeffekt med gammel metode

$([300 / 1000] \cdot 1)+([700 / 1000] \bullet 0)=0,3$

og forventet helseeffekt med ny metode

$([600 / 1000] \cdot 1)+([400 / 1000] \cdot 0)=0,6$.

I dette eksempelet gir gammel metode både høyere forventede kostnader (selv om det er billigste alternativ) og lavere forventede helseeffekter enn ny metode. Vi kan da konkludere at ny metode er kostnadseffektiv, også uten å vite noe om hva beslutningstaker regner som et rimelig forhold mellom kostnader og helseeffekter. Hvis vi setter opp en kostnads-effektbrøk (ICER) basert på dette eksempelet, får vi

$\mathrm{ICER}=(1900-1800) /(0,3-0,6)=-333 \mathrm{kroner} /$ frisk

I dette eksempelet er tolkningen at vi ved å velge ny metode heller enn gammel metode, vil spare kr 333 per person som blir frisk. Legg imidlertid merke til at det er mulig å få en ICER på -333 også ved resultatet (1 800-1 900)/(0,6-0,3), her er imidlertid tolkningen at man bruker kr 333 ekstra per person som forblir syk. Ved negative brøker må man sjekke om det er telleren eller nevneren som gir negative tall. I dette eksempelet fikk vi en negativ brøk, i de fleste tilfeller er brøken imidlertid positiv. Hvis både teller og nevner er positive, betyr dette at ny behandling er både mer effektiv og dyrere enn gammel behandling, med en ICER på 333 kroner per frisk, betyr det at det koster 333 kroner ekstra å oppnå en ekstra frisk person.

Et eksempel som er så enkelt som dette, kan lett regnes ut uten å sette opp en modellstruktur. De færreste reelle situasjoner er imidlertid så enkle og det er lett å tenke seg at problemstillingen kunne vært mer komplisert. I vårt eksempel blir pasienten frisk eller syk, men vi har blant annet ikke sagt noe om tidsperspektivet. Eksempelet over passer godt i en situasjon hvor pasienten blir akutt syk over en kortere periode. La oss nå anta at pasienten har en kronisk sykdom som forverres over tid. Effekten av ny metode er den samme, den dobler sannsynligheten for å være frisk (i dette eksempelet blir da frisk lik symptomfri), sammenliknet med gammel metode. Pasientenes bakgrunnsrisiko for å være syk øker imidlertid over tid, mens den i eksempelet over var konstant lik 0,7. En løsning i en slik situasjon kan være å sette opp et beslutningstre bestående av flere deler, hvor hver del representerer en ny tidsperiode med en ny sannsynlighet for å bli syk. Et eksempel på et slikt tre er vist $i$ figur 2. Tallene under boksene sier hvor mange pasienter som er hvor.

Selv i dette enkle eksempelet med bare to tidsperioder, er det lett å se at treet begynner å bli ganske stort og litt uoversiktlig. I tilfeller hvor metoden man evaluerer forventes å ha en langtidseffekt, eller påvirker overlevelse, kan det være aktuelt å følge pasienten i et livstidsperspektiv (10). Hvis hver tidsperiode her representerer ett år, må vi kanskje legge til tjue eller førti 
tidsperioder til treet i figur 2. Dette blir fort et uhåndterlig oppsett, selv om vi bare har to mulige utfall. Løsningen på dette er å heller sette opp en Markovmodell, enn et beslutningstre. Figur 3 viser en enkel Markov-modell basert på eksempelet over.

En Markov-modell som vist i figur 3, er bygd opp rundt to eller flere gjensidig utelukkende tilstander. I dette eksempelet er tilstandene syk og frisk. Slik vi har tegnet den nå, er det mulig for syke å bli friske og for friske å bli syke, alternativt kan de friske forbli friske og de syke forbli syke. De korte pilene representerer at man forblir i samme tilstand og de lange at man beveger seg mellom de to tilstandene. Mulige overganger mellom tilstandene kan i en Markov-modell kun gjøres etter en gitt tidsperiode, for eksempel en dag, en uke eller ett år. En slik tidsperiode kalles en syklus. Sykluslengden man velger avhenger av hvor ofte overganger mellom de ulike tilstandene vanligvis skjer. Hvis syklusen er ett år, legger man inn ettårige sannsynligheter for å bli syk hvis man er frisk, frisk hvis man er syk osv. Disse sannsynlighetene for overgang mellom tilstander kalles overgangssannsynligheter. Ett av poengene med Markov-modeller er at overgangssannsynlighetene skal kunne endre seg over tid.

Hver periode man tilbringer i en tilstand genererer en viss kostnad og helseeffekt. I eksempelet over vil hver syklus man tilbringer som syk generere en helseeffekt på 0 og en kostnad på 2000, mens hver syklus man tilbringer som frisk vil generere en helseeffekt på 1 og en kostnad på 0 . Det er også mulig å legge kostnader eller helseeffekter i selve overgangene, men det er ikke aktuelt i dette eksempelet. En typisk måte å bruke en Markov-modell på, er å kjøre den som en kohortanalyse, hvor man starter modellen med et gitt antall "deltakere", som så følges over en tidsperiode. For en videre innføring i Markov-modeller anbefaler vi artiklene til Sonnenberg og Beck (11) og Siebert med flere (12).

\section{OPPSETT AV MODELLSTRUKTUR}

Når man skal lage en helseøkonomisk modell, må man først bestemme struktur og dernest datakilder. Strukturen sier noe om hvilke hendelser eller tilstander man vil se på og hva slags forhold det er mellom dem. Eksempelvis kan en modell inneholde hendelsene hoftebrudd og død og forholdet mellom dem er at hoftebrudd øker risikoen for å dø. Hvor mye hoftebruddet øker risikoen for å dø er et eksempel på data som må legges inn i modellen. Når det gjelder oppsett av struktur, så er den generelle anbefalingen at denne skal være "consistent both with a coherent theory of the health condition being modeled and with available evidence regarding causal linkages between variables" (13). I eksempelet over forholdt vi oss ganske enkelt til frisk og syk, men det kunne for eksempel vært aktuelt å dele tilstanden syk i to: én lettere og én med mer alvorlige symptomer eller plager. Det kunne også vært aktuelt å inkludere risikoen for å dø. I praksis er det nødvendig å vite ganske mye om den sykdommen man

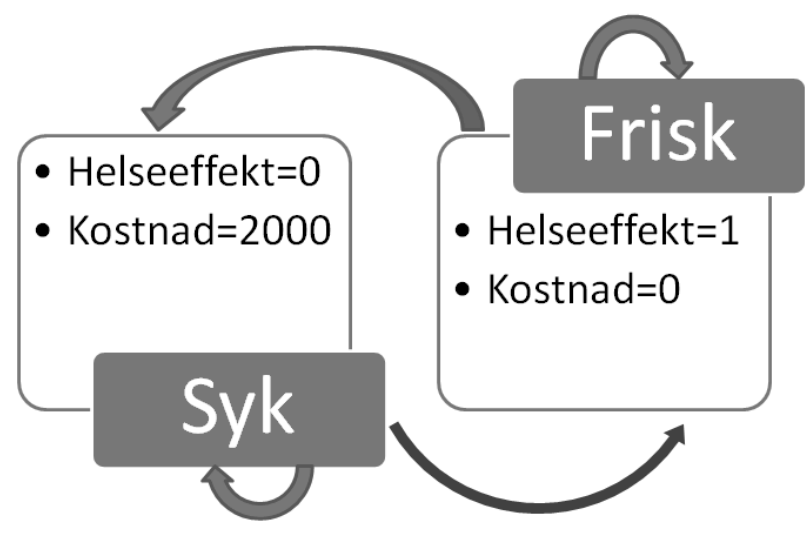

Figur 3. Enkel Markov-modell.

skal modellere, hva som er dagens praksis og hvordan et typisk pasientforløp ser ut for å sette opp en egnet struktur.

For økonomiske evalueringer gjelder de samme prinsippene som for en systematisk oversikt med tanke på at hendelser eller tilstander i modellen bør representere klinisk viktige endepunkter (14). Modellen bør prøve å fange alle aspekter av en sykdom som er viktige for pasienter. Det vil for eksempel innebære heller å inkludere hjerneslag som hendelse i modellen enn en endring i blodtrykk. En helseøkonomisk modell skal imidlertid være en forenkling som fokuserer på de elementene som har størst innvirkning på kostnader og pasientutfall og som er av betydning for forskjellen mellom de aktuelle behandlingene som sammenliknes (13). Dette betyr at detaljer som kan være avgjørende i møtet med den enkelte pasient noen ganger vil utelates, hvis de ikke er viktige for forskjellen mellom metodene som undersøkes.

Prinsippene bak modellering er felles på tvers av land og en modellstruktur kan derfor gjenbrukes hvis strukturen er satt opp rundt kliniske hendelser (selve sykdomsprosessen). For noen elementer kan det likevel finnes spesifikke anbefalinger i hvert enkelt land. I Norge har Helsedirektoratet nylig gitt ut en veileder for økonomisk evaluering i helsetjenesten (15) og Statens legemiddelverk har en egen veileder for søknader om opptak på blå resept (16). Veiledninger fra andre land er tilgjengelige på internett (17). De metodiske spørsmålene innen økonomisk evaluering er ofte gjenstand for diskusjon og det er mange ulike synspunkter. Dette gjelder for eksempel valg av helseutfall, foretrukket instrument for måling av helserelatert livskvalitet, størrelsen på diskonteringsraten, hvorvidt helseeffekter skal diskonteres med samme rate som kostnader og hvilke kostnader som bør inkluderes $i$ analysen. Vi har i denne artikkelen valgt ikke å gå nærmere inn på diskusjoner rundt disse metodiske spørsmålene, men heller fokusere på hvordan vi jobber praktisk med økonomisk evaluering på Kunnskapssenteret.

\section{Valg av data (input)}

Som nevnt over består en helseøkonomisk modell av en syntese av data. Hvordan går vi i Kunnskaps- 
senteret fram for å finne og for å velge ut de dataene vi baserer våre modeller på? Vårt utgangspunkt er det samme som når man utarbeider systematiske oversikter, nemlig at det gjelder å finne best mulige data og at ikke alle data er til å stole på (18). Vi presenterer noen avveininger ved valg av data under. En mer utfyllende veiledning finnes hos Coyle og medarbeidere (19).

\section{Overførbarhet og klinisk effekt}

Som nevnt i innledningen, er overførbarhet til norske forhold et viktig aspekt av en økonomisk evaluering som skal kunne legges til grunn for en norsk beslutning om innføring av en ny metode. Dette er et prinsipp som vi i størst mulig grad prøver å legge til grunn når vi velger datakilder. En viktig datakilde i en helseøkonomisk modellanalyse er de kliniske effektdataene. Våre økonomiske evalueringer vil i de fleste tilfeller ta utgangspunkt i effektdata fra en systematisk oversikt basert på internasjonal forskning, som er vurdert av våre forskere til å ha høy kvalitet. $\AA$ ha høy kvalitet $\mathrm{i}$ denne sammenhengen betyr at vi har tillit til at samleestimatet fra den systematiske oversikten er reproduserbart og ikke vil endres mye selv om det utføres nye studier.

\section{Epidemiologiske data og forholdet mellom absolutte og relative effekter}

Tilnærmingen vi legger til grunn $i$ våre modellanalyser er at anslagene for bakgrunnsrisiko $\mathrm{i}$ befolkningen $\mathrm{i}$ størst mulig grad baseres på norske epidemiologiske data. For at dette skal være mulig, er vi avhengige av gode norske registre og kohortstudier, samt publikasjoner basert på disse. Hvis slike ikke er tilgjengelige, leter vi etter epidemiologiske data fra land som likner på Norge med hensyn på sykdomsforekomst og risikofaktorer. Data fra kontrollarmen i intervensjonsstudier kan også være aktuelle å bruke, men regnes vanligvis ikke som optimale for dette formålet (19). Epidemiologiske bakgrunnsdata brukes til å modellere hva som skjer med pasienter som får dagens behandling, som noen ganger vil være ingen behandling.

For å få et estimat på hvilken absolutt effekt den nye metoden vil få hvis innført på en norsk befolkning, hentes behandlingseffekten fra den systematiske oversikten i form av en relativ effekt, som legges på den estimerte bakgrunnsrisikoen i Norge. For eksempel: En ny behandlingsmetode kan redusere risikoen for hjerteinfarkt med $20 \%$, men i en økonomisk analyse vil det være avgjørende å vite om utgangsrisikoen for hjerteinfarkt er 20 av 1000 (og dermed 4 færre infarkter) eller 400 av 1000 (og dermed 80 færre infarkter). I en modell vil behandlingseffekt sammen med tall for bakgrunnsrisiko avgjøre hvor stor sannsynligheten for overgang mellom ulike tilstander er.

\section{Pasientforløp og kostnader}

For å kunne estimere hva en sykdom koster å behandle, må vi vite en del om hvordan dagens pasientforløp er. Dette kan høres enkelt ut, men det kan være over- raskende vanskelig å finne ut hva som skjer med pasientene $\mathrm{i}$ dagens helsetjeneste og hvordan vi best kan reflektere dette i en modell.

Både ressursforbruk og priser er i stor grad spesifikke for hvert enkelt land. Man bør derfor velge norske kilder for disse dataene. I noen land finnes det sentrale registre over kostnader knyttet til ulike prosedyrer eller behandlinger. Det har vi foreløpig ikke i Norge, så priser henter vi gjerne fra kilder som regelverket for innsatsstyrt finansiering, takster fra fastlegetariffen eller liknende. Hvis den helseøkonomiske evalueringen baserer seg på en Markov-modell, som i eksempelet over, vil man trenge kostnader knyttet til de forskjellige hendelsene og tilstandene man velger å inkludere i modellen, i tillegg til selve behandlingskostnadene ved ny og gammel metode.

\section{Kvalitetsjusterte leveår (QALY)}

I en modell kan det inngå mange forskjellige sykdomsrelaterte hendelser og tilstander som en metode (behandling) kan påvirke. Hvilke og hvor mange hendelser og tilstander som er inkludert avhenger av sykdommens forløp, hva den aktuelle behandlingen kan påvirke og hvilken detaljgrad man ønsker eller har mulighet til å inkludere i modellen. I mange tilfeller er det slik at en og samme behandling påvirker flere forskjellige utfall, eksempelvis vil de nye orale antikoagulantene påvirke sannsynligheten for både slag, hjerteinfarkt, dødelighet og ulike typer blødninger (20). Hvordan kan man da best sammenlikne helseeffektene av de ulike behandlingsalternativene? En utbredt løsning innenfor helseøkonomien er å samle de ulike helseutfallene i noe som kalles kvalitetsjusterte leveår (quality adjusted life years, QALY) som fungerer som en slags felles "valuta" på helseutfall.

Kvalitetsjusterte leveår har to dimensjoner, en for tid (leveår) og en for kvalitet (helserelatert livskvalitet målt med forskjellige skåringsverktøy). Kvalitetsdimensjonen går fra 0 (død) til 1 (perfekt helse). Ved å gi levetid i sykdomstilstander en vekt mindre enn 1 , blir det også mulig å fange opp helseeffekter av behandling som kun er symptomlindrende og som ikke gir forlenget levetid. Jo verre en helsetilstand er, jo lavere QALY vekt vil den få og desto mer er det å vinne på behandlinger som kan forebygge eller behandle tilstanden. En kan tenke seg at det å være frisk har en vekt lik 1, mens det å ha en bestemt sykdom kan ha en vekt lik 0,7 . Hvis begge lever i to år, vil den friske generere $1 \cdot 2=2$ QALY og den syke generere $0,7 \cdot 2=1,4$ QALY. Det innebærer at man kan vinne 0,6 QALY $(2,0-1,4)$ hvis man kan gjøre den syke frisk. Legg imidlertid merke til at både den syke og den friske $\mathrm{i}$ dette eksempelet lever to år, slik at den rene leveårsgevinsten av denne behandlingen er lik null. Motsatt kan man tenke seg at selve sykdommen er symptomfri, slik at både syk og frisk har en QALY vekt på 1, men hvor den friske lever to år og den syke 1,4 år. En behandling som her kurerer den syke vil også generere 0,6 QALY $(1 \cdot 2-1 \cdot 1,4)$. 


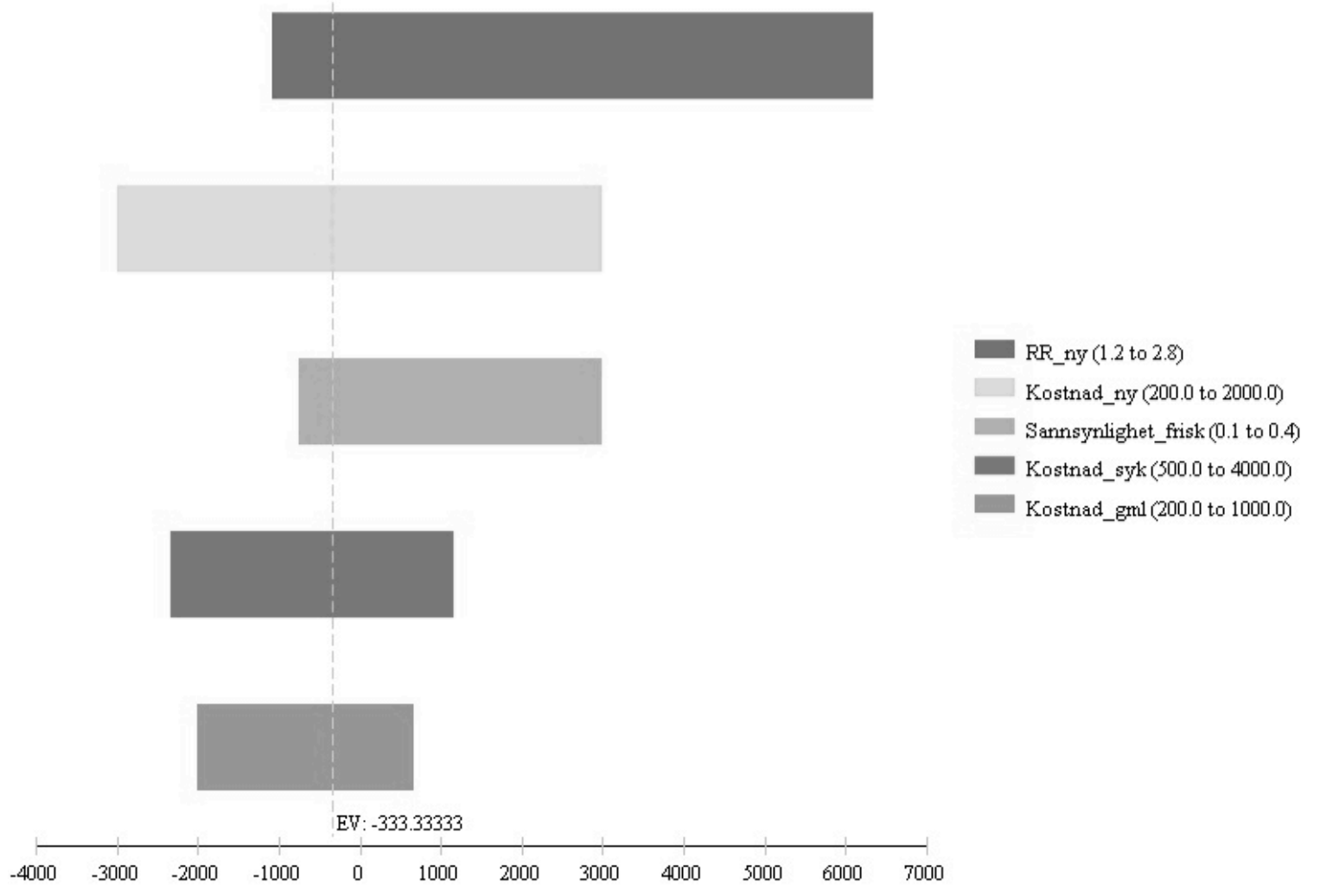

Figur 4. Eksempel på tornadodiagram.

Ideen bak kvalitetsdimensjonen er ganske enkelt at det er bedre (mer ønskelig) å være frisk enn å være syk, og at det er verre å rammes av alvorlig sykdom enn av mindre alvorlig sykdom.

Våre helseøkonomiske evalueringer er basert på publisert litteratur. Det innebærer at vi ikke måler helserelatert livskvalitet i den aktuelle pasientgruppen selv, men må finne vitenskapelige publikasjoner som vi kan hente tall for dette fra. Helst bør alle hendelser og tilstander som er med i modellen ha livskvalitetsvekter som kommer fra den samme målemetoden (målt med samme skåringsverktøy), ettersom ulike målemetoder kan gi ulike verdier (21). De randomiserte kontrollerte studiene, eller andre studier av effekt, har sjelden målt helserelatert livskvalitet på en måte som gjør at det er mulig å beregne helseeffekter i form av kvalitetsjusterte leveår. For å finne tall på dette må vi derfor gjøre egne litteratursøk etter studier som har hatt som spesifikt formål å måle helserelatert livskvalitet hos en pasientgruppe med den eller de sykdommene eller symptomene vi er ute etter. Aktuelle fremgangsmåter for å identifisere QALY-verdier er beskrevet av Brazier og medarbeidere (22). På samme måte som kostnader, vil QALY-verdier knyttes til de enkelte hendelser og tilstander man inkluderer i en modell.

\section{USIKKERHETSANALYSER}

En viktig del av enhver helseøkonomisk analyse er usikkerhetsanalysene (23). Når vi snakker om sensitivitetsanalyser, snakker vi ofte om deterministiske og probabilistiske sensitivitetsanalyser. I en deterministisk sensitivitetsanalyse har den aktuelle variabelen i utgangspunktet en spesifikk verdi. Eksempelvis kan vi si at sannsynligheten for å bli frisk er 0,3 . I en probabilistisk sensitivitetsanalyse er denne verdien 0,3 representert ved en sannsynlighetsfordeling med forventning 0,3 . Selv om fordelingen har forventning 0,3 , så kan den også anta andre verdier. Vanlige sensitivitetsanalyser er enveis sensitivitetsanalyser, probabilistiske sensitivitetsanalyser og analyser av verdien av videre forskning (expected value of perfect information).

Ved en enveis sensitivitetsanalyse undersøker man effekten av å variere en variabel mellom en øvre og en nedre grense. Noen ganger blir en serie av enveis sensitivitetsanalyser presentert som et tornadodiagram, hvor søylene er rangert etter hvor stor innvirkningen endring $\mathrm{i}$ hver enkelt variabel har på resultatet. Et eksempel på et tornadodiagram basert på det enkle beslutningstreet fra figur 1 er vist i figur 4. Hver søyle representerer endringen $i$ den estimerte kostnadeffektbrøken ved endring i en variabel.

I dette eksempelet representerer den stiplede linja som går loddrett gjennom alle søylene den estimerte ICER på -333 kroner/frisk. Her ser vi at det å variere effekten av ny behandling fra en RR på 1,2 til en RR på 2,8 har størst innvirkning på estimatet. Øvre og nedre grense på 1,2 og 2,8 kunne for eksempel være øre og nedre grense fra et $95 \%$ konfidensintervall omkring effektestimatet. Hvis RR=1,2 i dette eksempelet (dvs. at ny metode gir 20\% større sjanse for å bli frisk sammenliknet med gammel metode) vil ICER bli 6333 (dvs. vi betaler kr 6333 ekstra per ekstra person 
frisk). Hvis $R R=2,8$, så vil ICER bli -1074 (dvs. vi sparer kr 1074 per ekstra person som blir frisk). Nest størst innvirkning på resultatet har endring i pris for ny behandling fra 200 til 2000 kroner. Dersom prisen skulle bli 800 kroner lavere enn det vi har antatt, så ville ICER bli -3000 (vi sparer kr 3000 per ekstra frisk person). Dersom prisen skulle bli dobbelt så høy som antatt, så vil ICER bli 3000 (vi betaler 3000 kroner ekstra per person frisk). Dersom man har en deterministisk modell, kan denne presentasjonsformen være nyttig for å indikere hvilken usikker variabel som påvirker resultatet mest (24). Analysen er imidlertid svært følsom for hva som blir valgt som øvre og nedre verdi og bør derfor tolkes med varsomhet. Rangeringen av søyler kan fort bli annerledes dersom vi endrer de foreslåtte øvre og nedre verdiene for variablene. En tilleggsbegrensing med denne type analyse er at den kun viser effekten av å variere en og en variabel av gangen og ikke effekten av å variere alle de usikre variablene i modellen på en gang.

I en probabilistisk sensitivitetsanalyse tildeler man sannsynlighetsfordelinger til alle usikre variable som inngår i analysen. Man trekker så en verdi fra hver fordeling og regner ut resultatet. Dette blir gjentatt en rekke ganger, eksempelvis 1000 eller 10000 ganger. På denne måten kan man få et godt bilde av den samlede usikkerheten $\mathrm{i}$ resultatet knyttet til usikkerhet $\mathrm{i}$ variablene og også regne ut sannsynligheten for at et tiltak er mer kostnadseffektivt enn et annet. Typisk vil en probabilistisk analyse presenteres som et spredningsdiagram og også en akseptabilitetskurve hvor man viser sannsynligheten for at tiltaket er kostnadseffektivt ved ulike antatte "rimelighetsforhold" mellom merkostnader og mereffekter. Usikkerhetsanalysene som gjelder kostnadseffektivitet skiller seg imidlertid vesentlig fra tilsvarende analyser for effektstørrelser i det at man normalt ikke krever statistisk signifikant kostnadseffektivitet for å konkludere at et tiltak er mer kostnadseffektivt enn et annet. Hvis det eksempelvis kommer en ny metode på markedet og denne viser seg å være effektiv, men har et usikkert kostnadsbilde som gjør at man bare er $60 \%$ sikker på at kostnadene står i et rimelig forhold til effekten, vil en typisk helseøkonomisk evaluering likevel konkludere med at metoden er kostnadseffektiv $(24,25)$.

Analyser av verdien av forskning kan sees på som en videreutvikling av probabilistiske sensitivitetsanalyser, hvor man regner på gevinsten av å eliminere usikkerhet i beslutningen (25). Hvis man utarbeider en probabilistisk modell, er det anbefalt å presentere usikkerheten $i$ variablene $i$ form av en verdi-avforskningsanalyse, heller enn enveis sensitivitetsanalyser presentert $i$ et tornadodiagram. Metoden er beskrevet på norsk av Guttormsen og medarbeidere (27). Usikkerhetsanalysene i en helseøkonomisk evaluering vil på denne måten kunne være med på å gi indikasjoner på om det vil være hensiktsmessig å igangsette ny forskning for å redusere denne usikkerheten. Dersom usikkerheten i første rekke er knyttet til kostnadsbildet, vil en aktuell studie være å følge ressursbruken etter innføring av den nye metoden. Hvis derimot usikkerheten er størst rundt den kliniske effekten, vil det kunne være hensiktsmessig å starte en ny klinisk studie, fortrinnsvis et randomisert kontrollert forsøk. I Norge mangler det et helhetlig system for hva som bør gjøres når man identifiserer slike kunnskapshull. En løsning kan være å sørge for et bredere europeisk samarbeid om denne typen studier (28).

\section{REFERANSER}

1. Håheim LL, Mørland B. Medisinsk metodevurdering - en systematisk tilnærming for vurdering av den vitenskapelige dokumentasjonen av medisinske metoder. Norsk Epidemiologi 2003; 13: 309-14.

2. Lov om pasient- og brukerrettigheter (pasient- og brukerrettighetsloven). 2001.

3. Forskrift om prioritering av helsetjenester, rett til nødvendig helsehjelp fra spesialisthelsetjenesten, rett til behandling i utlandet og om klagenemnd (prioriteringsforskriften). 2001.

4. Kristiansen IS, Gyrd-Hansen D. Prioritering og helse - bør det innføres makspris på leveår? Tidsskr Nor Lageforen 2007; 127: 54-7.

5. Goeree R, Burke N, O'Reilly D, Manca A, Blackhouse G, Tarride JE. Transferability of economic evaluations: approaches and factors to consider when using results from one geographic area for another. Curr Med Res Opin 2007; 23: 671-82.

6. Drummond M, Barbieri M, Cook J, Glick HA, Lis J, Malik F, et al. Transferability of economic evaluations across jurisdictions: ISPOR good research practices task force report. Value Health 2009; 12: 409-18.

7. Anderson R, Shemilt I. The role of economic perspectives and evidence in systematic review. I: Shemilt I, Mugford M, Vale L, Marsh K, Donaldson C, red. Evidence-based Decisions and Economics, 2. utg. Oxford: Wiley-Blackwell, 2010.

8. Barbieri M, Drummond M, Willke R, Chancellor J, Jolain B, Towse A. Variability of cost-effectiveness estimates for pharmaceuticals in Western Europe: lessons for inferring generalizability. Value Health 2005; 8: 10-23.

9. Brennan A, Chick SE, Davies R. A taxonomy of model structures for economic evaluation of health technologies. Health Econ 2006; 15: 1295-310. 
10. Roberts M, Russell L, Paltiel A, Chambers M, McEwan P, Krahn M. Conceptualizing a model: A report of the ISPOR-SMDM modeling good research practices task force-2. Value Health 2012; 15: 804-11.

11. Sonnenberg FA, Beck JR. Markov models in medical decision making: a practical guide. Med Decis Making 1993; 13: 322-38.

12. Siebert U, Alagoz O, Bayoumi A, Jahn B, Owens D, Cohen D, et al. State-transition modeling: A report of the ISPOR-SMDM modeling good research practices task force-3. Value Health 2012; 15: 812-20.

13. Weinstein M, O'Brien B, Hornberger J, Jackson J, Johannesson M, McCabe C, et al. Principles of good practice for decision analytic modeling in health-care evaluation: Report of the ISPOR task force on good research practices - Modeling studies. Value Health 2003; 6: 9-17.

14. Drummond M, Sculpher M, Torrance GW, O'Brien BJ, Stoddart GL. Cost-effectiveness analysis. Methods for the Economic Evaluation of Health Care Programmes. Oxford: Oxford University Press, 2005.

15. Økonomisk evaluering av helsetiltak - en veileder. Oslo: Helsedirektoratet, 2012.

16. Retningslinjer for legemiddeløkonomiske analyser. Oslo: Statens legemiddelverk, 2012. www.legemiddelverket.no/Blaa_resept_og_pris/soeknad_om_refusjon/retningslinjer_for_legemiddeloekonom iske_analyser/Sider/default.aspx (07.04.13).

17. Pharmacoeconomic Guidelines Around The World: International Society for Pharmacoeconomics and Outcome Research (ISPOR), 2013. www.ispor.org/peguidelines/index.asp (23.07.13).

18. Jamtvedt G. Systematiske oversikte om effekt av tiltak. Norsk Epidemiologi 2013; 23: 119-124.

19. Coyle D, Lee KM, Cooper N. Use of Evidence in Decision Models. I: Shemilt I, Mugford M, Vale L, Marsh K, Donaldson C, red. Evidence-based Decisions and Economics, 2. utg. Oxford: Wiley-Blackwell, 2010.

20. Wisløff T, Ringerike T, Hagen G, Reikvam $\AA$, Klemp M. Efficacy and cost-effectiveness of new oral anticoagulants compared to warfarin for the prevention of stroke in patients with atrial fibrillation. Rapport fra Kunnskapssenteret nr 5-2013. Oslo: Nasjonalt kunnskapssenter for helsetjenesten, 2013.

21. Brazier J, Ratcliffe J, Salomon JA, Tsuchiya A. Methods for obtaining health state preferences: generic preference based measures of health and the alternatives. I: Brazier J, Ratcliffe J, Salomon JA, Tsuchiya A, red. Measuring and Valuing Health Benefits for Economic Evaluation. Oxford: Oxford University Press, 2007.

22. Brazier J, Papaioannou D, Cantrell A, Paisley S, Herrmann K. Identifying and reviewing health state utility values for populating decision models. I: Shemilt I, Mugford M, Vale L, Marsh K, Donaldson C, red. Evidence-based Decisions and Economics. Oxford: Wiley-Blackwell, 2010.

23. Briggs A, Claxton K, Schulpher M. Decision Modelling for Health Economic Evaluation. Oxford: Oxford University Press, 2006.

24. Husereau D, Drummond M, Petrou S, et al. Consolidated Health Economic Evaluation Reporting Standards (CHEERS) - Explanation and Elaboration: A Report of the ISPOR Health Economic Evaluation Publication Guidelines Good Reporting Practices Task Force. Value Health 2013; 16: 231-50.

25. Claxton K. The irrelevance of inference: a decision-making approach to the stochastic evaluation of health care technologies. J Health Econ 1999; 18: 341-64.

26. Moger TA, Guttormsen A, Kristiansen IS. Nyere metoder: Hvordan prioritere helsetiltak når både effekter og kostnader er usikre? Skriftserie 2010: 5. Oslo: Helseøkonomisk forskningsprogram ved Universitetet i Oslo (HERO), 2010.

27. Guttormsen A, Moger TA, Kristiansen IS. Trenger vi flere kliniske studier? Om verdien av mer informasjon i evaluering av helsetiltak. Skriftserie 2010: 6. Oslo: Helseøkonomisk forskningsprogram ved Universitetet i Oslo (HERO), 2010.

28. EVIDENT - Evidence Database on New Technologies [database]. https://evident.has-sante.fr/has/about.xhtml (08.04.13). 